\title{
Pollen-based evidence of extreme drought during the last Glacial (32.6 - 9.0 ka) in coastal southern California
}

Linda E. Heusser

5 Lamont Doherty Earth Observatory of Columbia University, Palisades, NY 10601 USA

Matthew E. Kirby

California State University, Fullerton, Department of Geological Sciences, Fullerton, CA 92834 USA

10

Jonathan E.Nichols

Lamont Doherty Earth Observatory of Columbia University, Palisades, NY 10601 USA

\section{ABSTRACT}

15 High resolution pollen analyses ofsediment core LEDC10-1 from Lake Elsinore yield the first, well-dated terrestrial record of sub-centennial-scale ecologic change in coastal southern California between $\sim 32-9$ ka.In the Lake Elsinore watershed, the initial, mesic montane conifer forests dominated by Pinus, and Cupressaceae with trace amounts of Abies and Picea were replaced by ansequence of multiple,extendedsevere mega-droughts between $\sim 27.5-\sim 25.5 \mathrm{ka}$, in which halophytic and xerophytic herbs and shrubs occupied an ephemeral lake.This prolonged and extended dry interval, which corresponds with warm waters offshore, imply strengthening of the North Pacific High and persistent below-average winter precipitation. The subsequent, contrastingmonotonic occurrence of montane conifersreflects little variation incold, mesic 
climate until $\sim 15 \mathrm{ka}$. Postglacial development of Quercus woodland and chaparral mark the

25 return to more xeric, warmer conditions at this time. A brief reversal at $\sim 13.1-\sim 12.1 \mathrm{ka}$,as reflected by an expansion of Pinus, is correlative with the YoungerDryas and interrupts development of warm, postglacial climate. Subsequent gradual expansion of xeric vegetation post - Younger Dryas denotes the establishment of a winter hydroclimate regime in coastal southern California that is more similar to modern conditions. Pollen-based reconstructions of

30 temperature and precipitation at Lake Elsinore aregenerally correlativewith pollen-based paleoclimatic reconstructions and foraminfera-based sea surface temperatures from Santa Barbara Basin in marine core ODP 893. The conspicuous absence ofthe $\sim 27.5-\sim 25.5$ kaglacial "mega-drought"in the Santa Barbara Basin pollen record highlights the sensitivity of Lake Elsinore to hydroclimate change, and thus, the importance of this new record that indicates that

35 mega-drought can occur during the full glacial when climatic boundary conditions and forcings differed substantiallyfrom the present.

\section{Introduction}

Ecologically and economically damaging extreme weather events such asdrought and winter stormscharacterize the Mediterranean climate of coastal southern California (CSC). The present "Great Drought" in California is extreme but not in terms of duration, especially for CSC where multi-decadal to centennial scale drought are inferredfrom the paleoclimatic record (Cook et al., 2004; Kirby et al., 2014). Predicted future changes in mean annual precipitation and

45 temperature seasonality is likely to impact vegetation and associated ecosystems of the California Floristic Biodiversity Hotspot, wherein Lake Elsinore (LE) is located (McDowell, 
2008; Williams, 2013). Regional-scale shifts in vegetation are already occurring (Myers et al., 2000; Brooks et al., 2002). Future water deficits are projected to result in widespread changes in the distribution and composition of CSCecosystems - the reduction and displacement of oak

50 (Quercus) woodlands northwards and/or to higher elevations (Kueppers, et al., 2005; Sork et al., 2010; McLaughlin and Zavaleta, 2012). Movement to higher elevations may mean southward to the coastal mountains (Loarie, et al., 2008). The key to predicting the future response of CSC ecosystems to climate change is a paleoperspective - i.e., past reconstructions of vegetation and its response to climatic change. Unfortunately for CSC, how vegetation responded to past

55 episodes of extended droughtand/or wetness, especially during the last Glacial, is poorly known.

Existing pollen-based reconstructions of glacial CSC climate vary indetail and temporal resolution. During the last interglacial (MIS 5e), pollen deposited in Santa Barbara Basin (SBB)(ODP Hole 893A) from drought-adapted, Mediterranean type vegetation was comparable to, or even more expansive, than present (Heusser, 1995; Friddell et al., 2002). A short, mid-

60 Wisconsinan pollen record in an organic deposit at Diamond Lake ( $\sim 30$ kmeast from Lake Elsinore) records expansion of more mesic montane ecosystems to lower elevations during nearpeak glacial conditions (Anderson,et al., 2002). Holocene pollen records from CSCare sparse and are generally low resolution (> centennial scale(Heusser, 1978; Davis, 1992; Cole and Liu, 1994; Heusser and Sirocko, 1997; Dingemans et al., 2014). An archival exception is a recent pollen

65 reconstruction from SBB indicating a significant vegetative response to thedrier-than-average Medieval Climate Anomaly (800-1300)andits transitioninto the early stages of the wetter-thanaverage Little Ice Age ( 1300-1400) (Heusseret al, 2014).

Here, we present the first continuous, multi-decadal resolutionpollen assemblage record from CSC (Lake Elsinore)spanningthe late last glacial (32-9 ka). We compare this record to 
70 nearby Santa Barbara Basin sea surface temperatures (SST) and its pollen data to examine marine - terrestrial similarities and differences.

\section{Background}

$75 \quad 2.1$ Setting

Originally called Lago Grande,LE is the largest $\left(\sim 15 \mathrm{~km}^{2}\right)$ natural lake in southern California(Fig. 1). Occupying a pull-apart basin 380 masl in the Peninsular Range, the lake is a shallow $(\sim 3-13$ m mean depth)but generally permanent lake, bordered by the Elsinore fault, one of the principal strands of the San Andreas fault system (Fletcher et al, 2006). Themain water

80 source for the lake isthe small, $\sim 1240 \mathrm{~km}^{2}$, drainage basin of the San Jacinto River,supplemented by direct runoff from theElsinore Mountains that rise abruptly $\sim 610 \mathrm{~m}$ above the western edge of the lake (Mann, 1951; Lichvar, 2003; Lawson, 2007). Runoff, which is positively correlated with precipitation, iswinter dominated and highly variable. During the last $\sim 200$ years, the lakehas desiccated four times during extreme droughtsand hasbriefly overflowed20 times

85 through a natural outlet $\sim 3 \mathrm{~m}$ above mean maximum depth (Lynch, 1931; Kirby et al., 2007).

The hydrology of LE reflects seasonal changes in annual precipitation/evaporation caused by broad changes in atmospheric circulation and oceanographic variability. The strength and position of the NE Pacific High pressure system (NEPH) redirects storm tracks to the north during the spring and summer and further south into California during the winter (Namias and

90 Cayan, 1981; Cayan and Peterson,1989; Seager et al., 2005; Cook et al., 2011). These large-scale atmospheric patterns, which control the average position of the polar front, affect the strength and character of the California Current System (CCS) and cause strong southward flow in 
summer and northward flow with cooler sea surface temperatures (SST) in winter (Hendy et al., 2002; Barron et al., 2003). A stronger polar jet produces increased storms in winter. During

95 winter, as the eastern Pacific subtropical high weakens, polar storm systems shift southward and produce over $80 \%$ of the annual precipitation (Cayan, 1984). In summer, northerly winds around the northeast Pacific subtropical high block northern storm tracks, cool SSTs, and produce persistent coastal upwelling. The subtropical North American Monsoon (NAM) provides limited summer precipitation but negligible to the lake's annual hydrologic budget (Adams and Comrie,

100 1997; Higgins et al., 1997). Tropical cyclones originating in the eastern Pacific Ocean contribute less than $20 \%$ of the total late-summer to early-fall precipitation and, like the monsoon, presently make no difference in the lake's annual hydrologic budget (Corbosiero et al., 2009; Ritchie et al., 2010). The semi-permanent high produces temperature inversions that trap air near the surface.Below the inversion layer, cool maritime air flows up the coastal slopes to $\sim 400$ mand 105 condenses into fog and fog-drip that averages $\sim 5.74 \mathrm{~cm} /$ month in May and June on the seaward side and $\sim 2.41 \mathrm{~cm} /$ month on the leeward side (Vogl, 1973).Inter-annual winter precipitation variability is modulated by ocean-atmosphere conditions in the tropical and extra-tropical Pacific such as the El Niño-Southern Oscillation (ENSO)and the Pacific Decadal Oscillation (PDO) (Castello and Shelton, 2004; Hanson et al., 2006; Kirby et al., 2010, 2014). During El Niño years, 110 drainage basins in the southwestern United States are more likely to experience higher stream flow and sediment flux than during La Niña years (Inman and Jenkins,1999; Farnsworth and Milliman, 2008; Warrick and Mertes, 2009; Gray et al., 2014).

High pressure over the North Pacific in summer and intensification of the Aleutian low in winter are reflected in seasonal contrasts of warm dry summer and cold wet winters that are 115 moderated by coastal waters. Modern marine and terrestrial temperature gradients along the 
California coast are remarkably similar. Average annual SSTshave a north to south gradient, ranging from $12^{\circ} \mathrm{C}$ to $16^{\circ} \mathrm{C}$, and average annual temperatures directly onshore are closely comparable, ranging from $11^{\circ} \mathrm{C}$ at $42^{\circ} \mathrm{N}$ to $17^{\circ} \mathrm{C}$ at $32^{\circ} \mathrm{N}$ (Lyle et al., 2010).Mean July coastal temperatures reflect local sea surface temperatures (Minnich, 2007). Average annual coastal

120 precipitation also has a very strong north-south gradient, ranging from $\sim 1700 \mathrm{~mm}$ to $<260 \mathrm{~mm}$.

Strong orographic temperature and precipitation gradients characterize the LE region. Topographic relief of this area is between 380meters at LE and up to 3,302 meters in the San Jacinto Mountains (Mann, 1951). In the Santa Ana Mountains, temperature depression averages $\sim 2.1^{\circ} \mathrm{C}$ for each $305 \mathrm{~m}$ increase of elevation (Vogel, 1973). Average annual temperatures

125 decrease from $\sim 17^{\circ} \mathrm{C}$ at LE $(\sim 380 \mathrm{masl})$ to $\sim 8^{\circ} \mathrm{C}$ on montane peaks. Average annual precipitation increases from $\sim 300$ mmat LE to680 mm on Santiago Peak (1,734 masl), where winter precipitation occasionally occurs as snow(Vogl, 1973).Above $\sim 1,000 \mathrm{~m}$ in the San Jacinto Mountains, the prevailing westerlies carry marine air which also moderates summer temperatures and produces fog and fog-drip many nights of the year (Vogl, 1972).Mountains act as "sky

130 islands", providing cooler temperatures for isolated ecosystems, and as "water towers" in storing and providing water to downstream ecosystems (Anderson and Goulden, 2011).

\subsection{Modern vegetation}

Elevational gradients in precipitationare reflected in step-likechanges in the natural

135 vegetation groups, as vegetation cover in this semi-arid climate is closely related to mean annual evaporative fraction (Anderson and Goulden, 2011). Vegetation around LE andon the lowelevation ( $400 \mathrm{~m})$ flat /gentle hilly topographyincludes a mosaic ofalluvial scrub, mixed chaparral(Ceanothus, Adenostoma, Q. dumosa, Q. wislizenii) and scrub oak woodland (Q. 
agrifolia, Poaceae), and California sage scrub (Artemisia californica, Salvia, Eriogonum),

140 generally require $\sim 300 \mathrm{~mm}$ of annual precipitation.Above $\sim 1300-1500 \mathrm{~m}$, scrub-shrub merges with oak (Q. chrysolepis, Q. kelloggii)and mixed evergreen oak-pine woodlands (Q.agrifolia, Q. kelloggii, Pinus coulteri) which require $\sim 625-650 \mathrm{~mm}$ precipitation and mean annual temperature of $12^{\circ}-\sim 15^{\circ} \mathrm{C}$. Montane coniferous forest $(P$. coulteri,P. jeffreyi,P. ponderosa, Calocedrus dedcurren,Cupressus forbesii, Pseudotsuga macrocarpa, and Abies concolor) occurs

145 above $\sim 1850 \mathrm{~m}$. Trans-montaneslopes support openPiñon and juniperwoodlands ( $P$. coulteri Juniperus californica), a disjunct, westernmost extensionof Great Basin and Colorado vegetation(Vasek and Thorne, 1977).

Plant communities that may occur at various elevations include riparian Populus/Platanus woodland and montaneQ. agrifolia/Alnus forest, fresh-water marshes (Carex, 150 Cyperus, Rorippa, Typha, Potamogeton),ephemeral vernal pools, alkaline flats,alluvial fans, playas, and fine alluvial soils,(Atriplex, and other salt-tolerant plants of which the Amaranthaceae are the most numerous) (Vasek, 1966;Barbour and Major, 1977;Vasek and Thorne, 1977; Davis, 1999; Anderson and Koehler, 2003; Lichvar, et al., 2003; Barbour, 2005; Clarke, et al., 2007). The upslope vegetation zonation and climate gradients are captured by 155 modern pollen assemblages from surficial samples taken in the cismontane region of southern California. In pollen assemblages from the San Jacinto Mountains, herbs dominatethe lowland ( $<775 \mathrm{~m}$ ), chaparral (Rosaceae with Quercus spp),occurs up to $1545 \mathrm{~m}$ interspersed with oakconifer woodlands. The higher elevation chaparral-conifer ecotone (Q. kelloggii and P. coulteri) is succeeded upslope by lower montane mixed conifer forests that include Quercus,Pinus, and

160 Cupressaceae (Vasek and Thorne, 1977). P.contortais prominent in pollen assemblages from the upper montane forest (Anderson and Koehler, 2003). Surface pollenassemblages from the 
Peninsularand Transverse Ranges of southern California show a similar altitudinal differentiation (Wahl, 2003a, b).Foothill and lower montane assemblages are dominated by Quercus.Pinusand Cupressaceae (Juniperus, Calocedrus) increase as elevation increases. Pinus, along with small 165 amounts of Abies, occurs in the montane zone.

Our useof modern pollen/vegetation relationships in the San Jacinto drainagebasin and the cismontane region as analogues for vegetation/climatic reconstructions from pollen deposited in LE is also based on observationsthat fluvial transport of pollen is the primary source of pollen deposited in lakes, and that pollen in rivers reflects the various ecosystems of the drainage basins

170 (Bonny, 1978; Brown, 2007; Zhu, et al., 2003). Reconnaissance studies of pollen in sediment samples from the San Jacinto River between $610 \mathrm{~m}-1630 \mathrm{~m}$, and from the surface ( 400m) of LE (Byrne, et al., 2004;) show the altitudinal zonation of montane conifers and lowland shrubs and herbs.Large lakes receive a large absolute input of pollen from regional sources via fluvial input (Matthias, 2014). Lesser amounts of pollen deposited in LE may be derived from emergent

175 and submergent littoral vegetation. Some local aeolian pollen transport is likelyhowever longdistance transport in a montane environment is more equivocal (Solomon, et al, 1982; McLennan and Mathewes, 1984; Jackson, 1999).

Our objective is to use high-resolution (decadal scale sampling) pollen analysis from a sediment core taken in Lake Elsinoreto reconstructpast vegetationbetween $\sim 32$ and $\sim 9$ ka. Our

180 goal is to develop a paleo-perspective of coupled ecologic - hydrologic dynamics that captures the range of variability from the last Glacial through the early Holocene for a better understanding of portending climate change and its potential ecologic consequences.

\section{Methods}




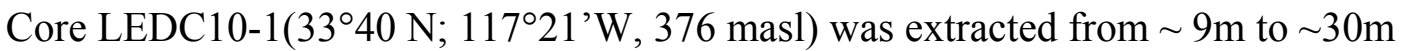
below the sediment/water interface.Each drive of the hollow stemmed, lined auger coring systemwas $0.61 \mathrm{~m}$. Recovery was $\sim 90 \%$.Initial data spanning $9-19$ ka are described in Kirby et al. (2013).

$190 \quad 3.2$ Pollen methods

Sediment samples $(\sim 5 \mathrm{cc})$ from core LEDC10-1, which were taken at $\sim 10 \mathrm{~cm}$ intervals between $10.37 \mathrm{~m}$ and $30.05 \mathrm{~m}$, were processed using standard procedures (Heusser and Stock, 1984). Known quantities of Lycopodium spores were added to each sample in order to calculate pollen concentration and pollen flux. Pollen recovery varied; however, in $\geq 270$ samples,

195300 pollen grains (upland, wetland, and aquatic) and spores were identified under a light microscope at 400x. Picea, which is absent from the region today, was included in the pollen sum. Reworked pollen (identified on the basis ofpollen morphology) was rare. Pollen identifications were based on reference collections of modern pollen and published references.Identification varied taxonomically - from generic to familial levels -due to factors

200 limiting identification of pollen of plant taxa, such as for the Cupressaceae. Inaperturate pollen grains thatmay have been produced byC. decurrens,Juniperus (J. californica, or J. osteosperma), and/or Cupressusare here referred to asCupressaceae(Munz, 1974). We note that Pinaceae, which were all identified as diplyxolon type, may representseveral species that range from chaparral and foothill woodland (P. attenuata, $P$. coulteri) to montane forest ( $P$. ponderosa).In our 205 summary pollen diagram, Abies/PiceaandRosaceae/ Rhamnaceae(Adenostoma, Cercocarpus, Ceanothus) are plotted together. Artemisia (sage) was separated from other Asteraceae. Obligate wetland taxa (Typha, Potamogeton, Sparganium,Myriophyllum, andIsoetes)are included in the 
pollen and spore sum. Pollen and sporeswere encountered less frequently, which are not shown in the summary pollen diagram, areincluded in calculating the pollen sum and relative abundance

210 of taxa shown in the summary pollen diagram.Plant nomenclaturefollows(Munz, 1974).(Pollen data will be available from NAPD).Pollen flux (grains $/ \mathrm{cm}^{2} / \mathrm{yr}$ ) quantifies the rate of pollen deposition in LE over the time of record

\subsection{Age model}

Age control is based on 24AMS radiocarbon dates from charcoal, wood, and/or seeds

215 (Table 1). An age model was developed usingthe Bacon 2.2 age-depth modeling program (Fig. 2).Infrared Stimulated Luminescence (IRSL) signals from single grains of K-feldspar from two sandy units were used to assess a section of the core were datable organic material was poorly preserved. This independent analysis supports our age model (Wu et al., in review).

\subsection{Statistical analyses}

Principal components (PC) analysis and cluster analysis is used to reduce the dimensionality of the pollen percent data and to identify the underlying relevant structure. The $\mathrm{R}$ Project statistical computing environment (R core team, 2014) was used for all statistical analyses. PC analysis of pollen percent data was performed by singular value decomposition using the function prcomp (.). We also performed an unconstrained cluster analysis by Ward's 225 method on a matrix of Euclidean distance.

Cluster analysis separated the pollen samples into three distinct groups, assigned arbitrary numbers 1 through 3 . The three groups determined by cluster analysis are also apparent in PC space (Fig. 3,5). Thebiplot shows the samples plotted by the PC axis 1 and 2 scores (Fig. 3). The colors and shapes of the points on this plot correspond with the group assignments from the 230 cluster analysis. Group 3, identified with blue X, is comprised of samples dominated by 
Cupressaceae pollen. This group is separated from the other two by PC axis 1 scores, as PC1 is most closely related to the percent Cupressaceae pollen. The other two groups are comprised of samples dominated by Asteraceae and Amaranthaceae pollen (group 3, red triangles) or Quercusand Pinuspollen (group 2, green +) and are separated by their PC2 axis scores. The

235 groupings identified by cluster analysis and Principal Components Analysis support the Pollen Zones assigned by visual inspection of the pollen percent data (Fig. 5).

\section{Pollen Results}

The relative abundance of the diagnostic taxa LEDC10-1 core aresummarized in Figure 4.The most striking aspect of the pollen recordis the contrast between the high-frequency

240 variations in herbaceous vegetation that bracket the prolonged, montonic dominance of Juniper and Pinus.

\section{$\underline{\text { PZI }(30.0 \mathrm{~m}-28.25 \mathrm{~m} ; 32.6-30.5 \mathrm{ka})}$}

A brief peak in Pinus(28\%) immediately followed by Cupressaceae peak (32\%)initiates

245 the base of the core(Fig. 4). Pinus values drop rapidly and remain low, in contrast to Cupressaceae, whichaverages $50 \%$ and reaches an acme $(70 \%)$ at the end of the zone, as does Typha ( $40 \%)$.Low values of Abies and Picea are sporadically present. Poaceae and Cyperaceae gradually increase, whereas Amaranthaceae, Asteraceae gradually increaseandpeak in the middle of PZI.The peaks in Typha, Asteraceae and Amaranthaceae are brief $(\leq 300$

250 yr).Eriogonumremains consistently low $(\leq 5 \%)$.

\section{$\underline{\text { PZII }(28.25 m-25.71 m ; 30.5-27.7 \mathrm{ka})}$}

Cupressaceaeranges between 20-40\%. Pinus ramps down to $\leq 10 \%$ as Amaranthaceae 
increase.Although minimal, Abies and Picea arebest represented in this zone.Asteraceae values

255 peak $(\sim 20 \%)$ in the middle of the zone. Artemisia andPoaceae remain as inPZI, while

Cyperaceae declines and then recovers. Excluding Typha, wetland and aquatic taxa

(Potamogeton,Myriophyllum,Sagittaria, Rorippa, Azolla,Isoetes) are only sporadically present.

\section{$\underline{\text { PZIII (25.71 m-23.5 m; } 27.7-25.2 \mathrm{ka})}$}

Cupressaceaedecreases from $\sim 40 \%$ at the base of the zone to $\sim 5 \%$.Pinusdrops to $<5 \%$ ).

The modest increase inQuercus $(\sim 8 \%)$ in this zone is not exceeded until PZVI.Two Amaranthaceae peaks( $\sim 50 \%$ at $\sim 25.3$ and $41 \%$ at $23.5 \mathrm{ka})$ bracket an interval that encloses Asteraceae maxima(53\% at $26.6 \mathrm{ka}$ and $45 \%$ at $25.6 \mathrm{ka})$. Except for one spike at $\sim 26.6 \mathrm{ka}$, Cyperaceae pollen forms $<\sim 15 \%$ of the pollen sum, as doesPoaceae, which begins to increase at

265 the end of PZ 3. The abrupt increase in Pinusat the base of this zoneinitiates a series of periodic fluctuations that offsetlower amplitude oscillationsthegraduallyincreasing, high abundance of Cupressus $($ mean $=43 \%$ ). Pinusoscillates down to $<5 \%$ between $\sim 26.5 \mathrm{ka}$ and $25.3 \mathrm{ka}$.

\section{$\underline{\operatorname{PZIV}(23.51 \mathrm{~m}-21.4 \mathrm{~m} ; 25.2-22.5 \mathrm{ka})}$}

The abrupt increase in Pinusto 54\% at the base of this zone initiates downward-ramping oscillations to $\sim 20 \%$ that are mirrored inthe low amplitude oscillations inthe rise of Cupressaceaefrom $\sim 10 \%$ to $\sim 59 \%$.A brief rise in Poaceae is followed by an extended increase in Cyperaceae, reach their highest values in the core. Alnus peaks briefly in this zone. A marked increased inTypha $(\sim 25 \%)$ briefly punctuates the Cyperaceae rise. Amaranthaceae and Asteraceae

275 are minimal $(\leq 5 \%)$. Azolla,Rorippa, Sagittaria,Potomgetonare present sporadically.Isoetes $(\sim 5 \%)$ occurs at the base of the zone and Myriophyllum increases to $15 \%$ at 23.4 kaand to $10 \%$ at 
$22.8 \mathrm{ka}$.

$\underline{P Z V(21.41 m-17.5 m ; 22.5-16.3 k a)}$

280 The predominance of Cupressaceae $\left(\sum 50 \%\right)$ is punctuated by periodic oscillations inPinus ( $\left.\sum 25 \%\right)$.Quercusincreases slightly in the middle of the zone. Abundance of herbaceous and shrub taxa, which remaincomparable to the low levels of the preceding zone, show muted oscillations. Wetland taxa (1\%) are rarely present.

\section{$285 \quad \underline{P Z V I}(17.5 \mathrm{~m}-13.5 \mathrm{~m} ; 16.3-10.4 \mathrm{ka})$}

Therise of Quercus to $\sim 39 \%$, therapid decline of Cupressaceae to minimal values $(\leq 1 \%)$, andasustainedincrease inRosaceae/Rhamnaceae ( $>15 \%)$ distinguish this zone from the rest of the core.Escalating from $<5 \%$ at the beginning of this zone to $39 \%$ at $\sim 13.2 \mathrm{ka}$, Quercusgradually ramps back to $15 \%$ at $10.8 \mathrm{ka}$. Asteraceae, Poaceae, Cyperaceae (comparable to values in PZIII)

290 show a substantial increase. Typhaand Alnus are continuously present in low amounts throughout the zone.Pinus, on the other hand, continues to oscillate at values maintained through most of the record, with the exception of PZIII and the latter part of PZI.

\section{$\underline{\text { PZVII }(13.5 m-10.4 m ; 10.4-9.0 \mathrm{ka})}$}

Thedominance of Asteraceae, the resurgence of Amaranthaceae and Poaceae characterize this zone.Asteraceae varies from $\sim 30 \%$ to $\sim 50 \%$ between $\sim 10.77-\sim 8.89 \mathrm{ka}$. The relative abundance of Amaranthaceae escalates to $30 \%$ at the top of the core; the relative abundance of Quercus fallsto background levels of $<5 \%$.

Principal components analysis distills the essence of pollen and spore data from core 
300 LEDC10-1 by reducing its dimensionality (Fig. 5). The importance of Cupressaceae in PZ I, II, IV and V is confirmed by high flux of Cupressaceae pollen in these zones. In PZ III, and PZ VII, positive PC axis 2 scores highlight the prominence of Asteraceae and Amaranthaceae. The inverse relationship between PC axis 2 scores and pollen flux, emphasize the role of halophytes and xerophytes in PZ II, III, VI, and VIII. High values of Quercus flux confirm the prominence

305 of Quercus (high negative scores of PC2) at the beginning of the deglacial $(\sim 14,400)$. The rapid decrease in Quercus flux is matched by decreasing negative values of PC 2. The striking minima of Asteraceae and Amaranthaceaeflux (PZ III and VII) contrasts with the prominence of these herbaceous taxa (high positive loadings) in PC2.

\section{5. Discussion}

5.1 Vegetation change between 32.6 and $9.0 \mathrm{ka}$

\section{$\underline{P Z I(32.6-30.5 \mathrm{ka})}$}

315 Cupressaceaewith lesser amounts of Pinus, dominated the LE drainagefrom $\sim 32.6-30.5$ ka(Fig. 4). Montane woodland and forests maywell have extended close to the shores of the lake. The assemblage suggests cool, wet conditions. It is interesting to note that Picea, which is no longer present in the region, occurs in trace amounts. Outliers of Picea sitchensis now occur on the California coast $\sim 300 \mathrm{~km}$ to the north where average annual temperatures and precipitation

320 are $\sim 3^{\circ}$ lower and $\sim 800 \mathrm{~mm}$ higher than Lake Elsinore. Components of chaparral/foothill woodland (Rosacea/Rhamnaceae and Quercus) were also present.A subsequent,rapid decrease in Pinussuggestsincreasingsummer drought, as Pinus is less drought-tolerant than 
Cupressaceae(Linton et al., 1998; Wilson et al., 2008). This is supported by a gradual coarsening of the clayey silts. Seasonal drought is also inferred from the expansion of low scrub

325 (Asteraceae) and of halophytes (Amaranthaceae), plants that colonize ephemeral, desert-like sites that become dry in summer (Branson, et al., 1967; Davis, 1999; Clarke et al., 2007). The expansion of emergent and submergent shoreline vegetation (Cyperaceae, Poaceae,Potamageton) also suggests overallregression of the lake in this zone. Abrupt drops in lake levels are implied by rapidincreases in herbaceous vegetation (tules/cattail marshes:

330 Asteraceae, Amaranthaceae, and Typha)closer to the lake depocenter $\sim 31 \_\sim 30 \mathrm{ka}$. Pollen flux (grains $/ \mathrm{cm}^{2} / \mathrm{yr}$ ) in the clayey silts is high (Fig. 5). This is likely a function of sedimentation (hydrodynamically, pollen grains are approximately the same size as silt and clay), and of enhancedpreservation in organic-rich silts and clays (Sangster and Dale, 1961; Tschudy, 1969).

\section{$335 \quad$ PZ II $(30.5-27.7 \mathrm{ka})$}

A step-like decrease in Cupressaceae abundanceand an abrupt decrease in total fluxto minimal values occurred between $\sim 30.5-27.7 \mathrm{ka}$ ) (Fig. 4-5). The decrease in Cupressaceae, the substantial increases inPinus, andthe presence ofmontane taxa (Picea and Abies) are interpreted as evidence of lowannual temperatures.Fluctuations in Cupressaceae and Pinus may reflect

340 variations in precipitation in the Lake Elsinore watershed. Increased summer drought is suggestedby the increasingprominence of Amaranthaceae and Asteraceae (common components of seasonally-dry, ephemeral sites and scrub)(Koehler, et al, 2005).

\section{$\underline{\text { PZ III }(27.7-25.2 \mathrm{ka})}$}

345 In this Zone, repeatedhigh-frequencyoscillations in the relative abundance and total flux of 
halophytic and xerophytelittoral vegetation (Cluster 1, Amaranthaceae and Asteraceae)implylengthy intervalsin which the lake regressed and the shoreline prograded basinward, allowing salt- and drought-tolerant vegetationto expandperiodically around and onto the former lake bed during persistent, extremewinter (and summer)droughts(Davis, 1999)(Fig 350 4,5).Minimal relative abundance of montane conifers (Cupressaceae and Pinus) also suggests intervals of decreased effective moisture in the San Jacinto River watershed.The substantial increasein xerophytic and halophytic vegetation is consistent with growth a sandy substrate (Fig. 5). Minimal total pollen flux $\left(<81,00\right.$ grains $\left./ \mathrm{cm}^{2} / \mathrm{yr}\right)$ is consistent with oxidation and degradation of pollen deposited on a coarse, sandy substrate (Solomon, et al., 1982; Fall, 1987; Campbell,

355 1999; Davis, 1999; Lebreton, et al., 2012). The relative abundance of sand, which reached values as high as $80 \%$, was likely formed by a prograding littoral zoneas lake level regressed (Wu et al., in review).

It is possible that lake level regression and sand deposition is also related to tectonic activity on the Elsinore and nearby San Jacinto fault zones. One main shock has occurred along

360 the Elsinore fault and five main shocks occurred along the San Jacinto fault zone during historic time (Wyss et al., 2000). Over the past $40 \mathrm{ka}$, the mean horizontal slip on the Elsinore fault rate is $\sim 1.6 \mathrm{~mm} / \mathrm{yr}$ (Fletcher et al., 2011). Faulting is unlikely to account for more than $1-2 \mathrm{~m}$ of faultgenerated lake base level change; whereas, hydrologically-forced lake base level change of up to $13 \mathrm{~m}$ has been noted in the historical record (Vaughan et al., 1999; Kirby et al., 2004). Moreover, 365 the minimal relative abundance of montane conifers Cupressaceaeand Pinus) correlative to the sandy unit cannot be explained reasonably by local tectonic activity.

Based on limited vertical displacement along the Elsinore fault and the altered montane contribution correlative to the sandy unit, we favor the climatic interpretation that PZ III 
represents a protracted interval of below average winter precipitation and annual drought.

370

$\underline{P Z I V(25.3-22.5 k a)}$

Between $25.3-22.5 \mathrm{ka}$, Cupressaceaewerethe major component of the montane coniferous woodland that surrounded LE. The abundance and high flux rate of Cupressaceae- and Pinus-dominated pollen deposited in Lake Elsinoreindicates the expansion of montane forests

375 close to the lake, which would imply treeline lowering $>1000 \mathrm{~m}$ and estimated temperature depression on the order of $\sim 11^{\circ} \mathrm{C}$ (Andersonand Koehler, 2003). The minimalamount ofQuercus. and Rosaceae/Rhamnaceae, may have beenderived from a limited area of oak scrub/chaparral that bordered the shore. Relative absence of Asteraceae, Amaranthaceae, and submergent vegetation implies lake levels were higher than in PZ III. Initially, wetland composed of Typha

380 and Cyperaceae grew near the core site. As the lake level transgressed, marshland decreased and shallow-water aquatics (Myriophyllum) developed. The pulsating increase in Cupressaceae (PC 1) and correlative decrease in Pinus may reflect increased precipitation and/or decreased evapotranspiration due to lower summer and winter temperatures. The abrupt change in relative abundance and flux of pollen from drought-adapted vegetation to emergent and submergent

385 aquatic vegetation corresponds temporally with the correlative change in the depositional environment - an abrupt shift from an organic-poor sandy silt/silty sand (shallow water) to an organic-rich, poorly to well-laminatedclayey silt (deeper water) (Kirby et al., in preparation) (Fig. $5)$.

Cupressaceae-dominated montane woodlands and forest apparently covered much of the 
San Jacinto River catchment andthe shores of LE between $\sim 22.5$ and $\sim 14.4$ ka. Subtle reduction in the prominence of Cupressaceaeand increase in the relative proportion ofPinuscontinued through the last glacial maximum; however, the relative abundance and flux of Cupressaceae

395 was always greater than that of Pinus. AlthoughCupressaceae-typepollen has been consideredasover-representedin relation to Pinus(Hidalgo et al., 1999), in modern pollen assemblages from the cis-montane region of southern California, the relative proportions of Pinus and Cupressaceae are considered to be valid representatives of their presence in the landscape (Wahl, 2003b). In this zone, we interpret the overall decrease in the relative abundance

400 of Cupressaceae and increase inPinus, which is less tolerant of summer drought, as evidence of increasing effective soil moisture due to decreasing summer drought and/or increasing effective precipitation(Wells, 1979; Linton et al., 1998; Mueller et al., 2005; Minnich, 2007; Willson et al., 2008). At no time during this 8.1 ka interval does the vegetation indicate significant drought. High lake levels during the LGM are inferred from the very low amount of littoral-zone pollen 405 and the high rate of conifer pollen deposited in LE. The absence of littoral zone vegetation may reflect increased precipitation/runoff, which caused high lake levels to rise above the natural outlet, flooding and destroying littoral vegetation. We posit that the high flux of pollen deposited annually in this zone likely reflect increased precipitation and runoff in the LE watershed that also resulted in rapid transport and deposition of pollen and other silt and clay size particles in 410 LE (Fig.5).

\section{$\underline{P Z V I(14.4-10.8 \mathrm{ka})}$}

The deglacial $(\sim 14.4-10.8 \mathrm{ka})$ is distinguishedby the prominence of Quercusabundance and flux (Fig. 5), the sudden demise of Cupressaceae, and the increased presence of chaparral 
415 taxa(Rosaceae/Rhamnaceae). The relative abundance of oak woodland and chaparral deposited in LE approachesrecent values (Byrne et al., 2004). In sharp contrast to the precedingrelatively low-amplitude variation in basically two pollen types (Cupressaceae and Pinus), the dynamic deglacial pollen recordconsists of large- amplitude Quercus and Pinus-dominated oscillations, accompanied by a diversity of arboreal and nonarboreal pollen types. Theinitialrise

420 ofQuercus $(14.5-13.1 \mathrm{ka})$ corresponds withthe Bølling-Allerød warming, and the subsequent Pinus peak corresponds withYounger Dryascooling ( 13.1 - 12.1 ka) (Kirby et al., 2013).The, stepwise decline inthe montane conifer Cupressaceaeand the increase in Quercus woodland implies overall higher summer temperatures. The abrupt decrease in Cupressaceae andPinus flux at the beginning of this zone may reflect a substantial decrease in precipitation in the LE

425 watershed. The overall reduction in pollen flux undoubtedly reflects oxidation of pollen in the overall shallower lake and its now well-mixed, more oxic profundal zone (Sangster, 1961; Bryant et al., 1994; Kirby et al., 2005; 2013) (Fig. 5).

Episodic variations in herbaceous (Asteraceae, Rosacea/Rhamnaceae), emergent (Cyperaceae, Poaceae, Typha), and aquatic(Potomageton) vegetation imply shorelines close to 430 the depocenter - a shallowing lake reflectinghigher summer temperatures and/or decreased precipitation/runoff (Bryant et al., 1994; Davis, 1999; MacDonald et al., 2008; Kirby et al., 2005, 2013). The relatively high carbonate content of the sediment, which is regarded as a proxy for warmer epilimnion summer temperature and decreased water depth, supports this interpretation (Kirby et al., 2013).

$\underline{\text { PZ VII }(10.8-9.0 \mathrm{ka})}$ 
We interpret the abundance of pollen from halophytic vegetation (Amaranthaceae) and semi-arid scrub (Asteraceae) as evidence of increased summer drought between $\sim 10.8$ and $\sim 9.0$ ka. Thevery low total flux rate may reflect significantly reduced precipitation and runoff (Fig. 5).

440 This early Holocene herbaceouspollen assemblage resembles pollen assemblages deposited between $27.5-25.3 \mathrm{ka}) 5 \mathrm{ka}$,a lengthy interval that we termed a glacial megadrought.

\subsection{Coastal southern California: Lake Elsinore and Santa Barbara Basinpollen records}

To develop a regional overview of vegetation change in CSC between $\sim 32 \mathrm{ka}$ and $\sim 9 \mathrm{ka}$,

445 we compare the pollen record from Lake Elsinore (this paper)with the pollen record from marine core ODP893A in SBB (Heusser, 1995). At present, there are no other continuous, high resolution records ( $\sim 88$ years between samples in Lake Elsinore and $\sim 218$ years between samples in ODP893A) of terrestrial ecosystemsin coastal southwest North America.Although both localities (LE and SBB) are surrounded by summer dry/winter wet Mediterranean plant

450 communities that range from montane forests to lowland chaparral, there are significant differences between the source of the pollen and the depositional sites. Pollen assemblages deposited in LE, a pull apart basin, integrate pollen from vegetation of the San Jacinto drainage $\left(\sim 1240 \mathrm{~km}^{2}\right)$, including the broad $(40 \mathrm{~km})$, rolling hills of the San Jacinto Valley, as well as local runoff from the Elsinore Mountains. Pollen assemblages deposited in SBB, a deep, anoxic basin,

455 integrate the composition and seasonal pollen production of vegetation in the large watershed of the Santa Clara River $\left(4100 \mathrm{~km}^{2}\right)$ that drains the nearby Transverse Mountains and a narrow coastal plain (Heusser et al., 2014). Although average annual temperatures in LE and Santa Barbara (SB) are similar, LElies $\sim 40 \mathrm{~km}$ inlandon the leeward side of theElsinore Mountains where average summer temperatures are $\sim 8^{\circ} \mathrm{C}$ higher than on the coast atSB. Average annual 
460 precipitation in LE ( $\sim 304 \mathrm{~mm})$ is approximately half of precipitation in Santa Barbara (Vogl, 1972).

The similarity of the basic structure of the relative abundance of oak (Quercus) in both sites is striking (Fig. 6). Quercus values initially oscillate between $5-10 \%$ and subsequently level at minimal values between $25-15 \mathrm{ka}$. Rapid deglacial fluctuations during the deglacial may be

465 correlative; however, the abrupt rise at $\sim 13.5$ to Holocene Quercus values in SBB apparently occurs $\sim 1000$ years after LE. This difference may reflect the usual age-model caveats (e.g. differences between oxygen isotope- and radiocarbon - based age-models) The postglacial decrease in Cupressaceae, the dominant taxon of both full-glacial records, also reflects an apparent 1000-year offset. A major difference between the early Cupressaceae records is the

470 step-like decrease of Cupressaceae in LE. Relative abundance plunged from $\sim 60 \%$ at the beginning of the record to $\sim 10 \%$ at $\sim 26 \mathrm{ka}$, and subsequently rose to maximum glacial values $(\sim 60 \%)$ at $23.2 \mathrm{ka}$. In SBB, however Cupressaceae varied within full-glacial values from the beginning of the record. In the early glacial record from LE $(\sim 32-\sim 25 \mathrm{ka})$, repeated, highfrequency variation in the relative abundance of herbs (Artemisia, Amaranthaceae, and

475 Asteraceae) differ markedly from the SBB low-frequency mode of herbal abundance that continued until $\sim 13.5 \mathrm{ka}$. We suggest that the extended oscillations of pollen from halophytic and xerophytic vegetationreflect dynamic changes in the source and depositional environment -a seasonally-dry lake surrounded bysemi-desert,rolling hills. The comparative absence of similar halophytic and xerophytic vegetation in the SBBrecord suggeststhat on the coast, increased 480 effective moisturemay have been buffered by persistent onshore fog.

Although the mean relative abundance of Pinus pollen deposited in LE and SBB is surprisingly similar (Pinus pollen can be over-represented in marine sediments [Heusser and 
Balsam, 1977]), the basic trends in Pinuspollen abundance differ. In SBB, the relative amount ofPinus decreases overall from $\sim 32$ ka until the LGM, whereas in LE, Pinus abruptly decreases 485 at $32 \mathrm{ka}, 30 \mathrm{ka}$, and $25 \mathrm{ka}$, and then gradually increases until $\sim 15 \mathrm{ka}$. In the LE Pinus record, the lengthy decrease from 14.8ka to 12kacontrasts with a correlative increase in Pinus at ODP893A. This may reflect the differential input of Quercus at the two sites.

Pollen data from LE and SBBprovide a continuous, regional pattern of CSC vegetation and climate change from $32 \mathrm{ka}$ to $\sim 10 \mathrm{ka}$ that is supported by other CSCpaleoenvironmental

490 reconstructions. Full glacial, cool, wet conditions have been inferred from the presence of montane vegetation at low elevations in Los Angeles and evidence of glaciation in the San Bernardino Mountains (Anderson, 2002; Owen et al., 2003; Coltrain et al., 2004; Ward, 2005). In nearby Diamond Valley, montane Juniperus expanded to lower elevations at $\sim 41 \mathrm{ka}$ (Anderson et al.,2002) and in southeastern California, Cupressaceae and Pinus dominated full-glacial 495 sediment (Davis, 1999; Atwater, 1986).Analysis of Baldwin Lake sediments deposited between $\sim 27-\sim 20$ ka are interpreted as evidence of lake regression and formation of a playa lake (Blazevic, et al., 2009). At Zaca Lake, $50 \mathrm{~km}$ northeast of SBB, fluvial tufa deposits suggest increased precipitation, approximately at 11,17, and $19 \mathrm{ka}$ (Ibarra et al., 2015). Floral and lithologic evidence of glacial/postglacial evolution of cold, wet to warm, dry climates has been

500 documented on the Channel Islands and at LE(Anderson et al., 2008, 2010; Kennett, 2008; Kirby et al., 2013).On the north coast of California and Oregon, cool wet glacial climates supported montane coniferous forests that were replaced by lowlandSequoia sempervirens (coastal redwood) and $P$. sitchensis rainforests after $\sim 15 \mathrm{ka}$ (Pisias, et al, 2001). Indrier regions inland,Quercus woodland expanded $\sim 15 \mathrm{ka}$, as in LE. 


\subsection{Paleoclimate change in coastal southern California and offshore waters of the North Pacific}

The interaction between atmospheric circulation (the Aleutian Low and North Pacific

510 High) and northeast Pacific sea surface temperature produce climate variations thatdrive largescale variations in the composition and distribution of terrestrial ecosystems in CSC (Namias and Cayan, 1981; Trenberth and Hurrell, 1994; Harrison, 2003; Diffenbaugh and Ashfaq, 2007).Strong correlations between marine and continental records from coastal northern California and Oregon have shown that the response time of the two regions to changes in

515 millennial scale climate forcing is similar, and that oceanographic conditions on these time scales have a direct impact on coastal climates (Pisias et al., 2001).

In Figure 7, we compare the faunal response of the southern California margin with floral response onshore to climate variability between $\sim 9 \mathrm{ka}$ and $\sim 32 \mathrm{ka}$. We use two planktonic foraminiferal assemblages in SBB that are associated with cool waters (Factor 1, sinistral $N$.

520 pachyderma dominated), and with warm, stratified water (Factor 3, G. bulloides, N.incompta dominated). $N$. pachyderma is presently found in $6^{\circ}-8^{\circ} \mathrm{C}$ subpolar waters; $N$.incompta is presently found in SB waters that range from $14^{\circ}-17.5^{\circ} \mathrm{C}$ (Hendy, 2010).

We use floral assemblage PC1 from LE as a proxy for variations in effective moisture, which is a function of temperature and evaporation (Shinker and Bartlein, 2010). When effective

525 moisture is high, there is little moisture stress on plants and precipitation and runoff are high. The converse is true when effective moisture (EM) is low. Positive values of floral assemblage PC1 indicate the abundance of upper, montane,Cupressaceae (juniper)-dominated woodlands, in which annual precipitation is $\sim 1000 \mathrm{~mm}$ (Fig. 3).Negative values indicate abundant 
Amaranthaceae-Asteraceae, halophytic and xerophytic vegetation of ephemeral playa lakes and

530 vernal pools in which annual precipitation is $\sim 500 \mathrm{~mm}$ (Thompson, et al., 1998; Wahl, 2003a, b). Temperature depression averages $\sim 2.1^{\circ} \mathrm{C}$ for each 300 -m increase of elevation in the San Jacinto Mountains (Vogl, 1972).

Between 32and 27.7 ka,effective moisture decreases in a step-like pattern. A major drop in EM $(29.5-28.9 \mathrm{ka})$ occurs immediately after a sharp decrease in the subarctic state of SBB

535 waters. The triple sequence of effective moisture minima at $27.5 \mathrm{ka}, 26.6 \mathrm{ka}$, and $25.5 \mathrm{ka}$, each lasting $\sim 500$ years, represent drought-like conditions that persist for over $\sim 2000$ years. A similar duration(500 yr) of drought is inferred from late Holocene sediments from Zaca Lake, located 50 km northfrom SBB (Kirby et al., 2014). This drought similarityindicates that our proposed glacial megadroughts are not without more recent analogs; moreover, it suggests that megadroughts are a feature during both glacial and-interglacial conditions (Kirby et al., 2014).In $\mathrm{SBB}$, during this terrestrial drought interval, a triple sequence of low values of the subarctic faunal factor generally correspond with low effective moisture onshore and with high values of the warm faunal factor.The gradual rise and sustained,monotonic high levels of effective moisture that continued until $\sim 16.5$ ka correspond with high values of the subarctic waters but 545 they do not mirror the rapid and abrupt shifts in the subarctic and warm states of SBB.In like manner, the gradual, postglacial decrease in effective moisture corresponds with a series of steplike changes in SBB. We interpret thepeak in effective moisture at $\sim 12.5 \mathrm{ka}$, which corresponds with a comparable increase in the subarctic state and decrease in the warm state of surface waters in SBB, as clear evidence of the Younger Dryas climatic event. The general correspondence between offshore (SBB) temperature and onshore (LE) effective moisture suggests a direct buffering of continental temperatures by the thermal inertia 
of coastal waters as well as a linked response to large-scale atmospheric reorganization over the north Pacific and coastal southwest United States (Herbert et al., 2001; Barron et al., 2003; Lyle et al., 2010, 2012; Pisias et al., 2001).

\section{Conclusions}

Pollen analysis of core LEDC10-1 from Lake Elsinore, California provides the first continuous, decadal-scale recordof the response of CSCecosystems to climate change from $\sim 32$ to $\sim 9$ ka. mesic montane vegetation that initially dominated the site was replaced by high-frequency

560 shifts to arid, herbaceous (Amaranthaceae, Asteraceae, Artemisia) vegetation that lasted from $\sim 27.5-\sim 25.5 \mathrm{ka}$ - an unprecedented glacial megadrought. Minimal pollen flux at the same time reflects frequent, abrupt changes in the depositional environment likely associated with the rapid migration of the littoral zone; this also suggests persistentand sustained drought. Subsequent monotonic development of montane conifer forests (Cupressaceae with lesser amounts of Pinus),

565 indicative of lower temperatures and increased precipitation, continued unabated until $\sim 16 \mathrm{ka}$. Rapid fluctuations in Quercus and other semi-arid lowland vegetation characterize the late Glacial to Holocene transition. The late-glacial resurgence of drought-adapted vegetation and low values of pollen flux resemble conditions not unlike those of the Glacial megadroughts in Lake Elsinore between $\sim 27.5-\sim 25.5 \mathrm{ka}$, and of Holocene multi-century droughts In SBB and at

570 Zaca Lake during the Medieval Climate Anomaly (Heusser, et al., 2014; Kirby, et al., 2014).

Comparisons between marine surface water conditions (planktonic fauna) and terrestrial conditions (pollen-based proxy of effective moisture) show broad scale similarities.Correspondence between major climatic events, such as the Younger Dryas and 
Interstadials 2-5, suggest that nearby marine conditions may modulate the terrestrial response to

575 climatic forcing

The similarity of the broad patterns of terrestrial vegetationchange that are reconstructed from Lake Elsinore and from Santa Barbara Basin (ODP Site 893) provide a regional synthesis of CSC vegetationchange between $\sim 32-\sim 9 \mathrm{ka}$. However, there are significant differences . The extreme Glacial megadroughts that lasted from $\sim 27.5-\sim 25.5$ ka inland at Lake Elsinore are not recorded by the pollen data from the Santa Barbara coast. The Lake Elsinore record apparently captures the response of semi-arid ecosystems to local edaphic and climatic change. The conspicuous absence of the $\sim 27.5-\sim 25.5$ ka glacial "mega-drought" in the Santa Barbara Basin pollen record highlights the sensitivity of Lake Elsinore to hydroclimatic change, and thus, the importance of this new record. These results indicate that megadrought can occur even during 585 the full glacial climatic boundary conditions and forcings.

Multi-century megadroughts in CS occur in both Glacial and Interglacial conditions. The duration of these arid intervals exceed anything observed in the recent or tree-ring records for CSC (Cook, et al., 2004). As climate continues to change, might these megadroughts represent possible analogs for the future hydroclimatic state in CSC?

\section{Acknowledgements:}

The authors would like to thank the Editor and reviewer (J. Carrión and R. S. Anderson) for their help in developing this paper. This study was supported by U.S. National Science Foundation

595 Grants 031511,0731843 , and 1203549 to MEK. Coring was supported by the American Chemical Society Petroleum Research Grant \#4187-B8 to MEK. We thank Mr. Pat Kilroy (lake 
manager), the City of Lake Elsinore, John Gregg and Gregg Drilling and Testing, Inc., Joe Holbrook, M.F.A. and the CSUF School of Theatre and Dance for recovering and opening the cores.

600

\section{Figure Captions}

Figure 1 Map of Southern California showing location of Lake Elsinore and ODP Site 893, Core

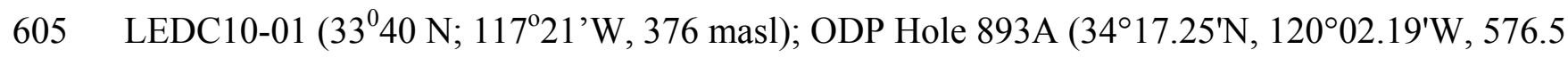
mbsf), Zaca Lake, and the San Jacinto and Santa Anna Mountains. Inset shows location of study area in relation to the U.S.

Figure 2. Age model for LEDC10-1 produced by BACON 2.2 program, using age data shown in 610 Table 1.

Figure 3. Principal Components (PC) Analysis of pollen data from Core LEDC10-01. Cluster 1 (red triangle), which includes Asteraceae, Amaranthaceae and Pinus, dominates pollen III and VIII. Cluster 2 (green +), composed of Quercus, dominates pollen zone VI. Cluster 3 (blue x),

615 composed of Cupressaceae, dominates pollen zones 1,II, IV, and V. PC1, and PC 2 explain 56\% and $19 \%$ of the variance respectively. 
Figure 4. The relative abundance of selected pollen taxa in Core LEDC10-01. Pollen zones (IVII) were constructed using the results of cluster and PC analysis. Ages of dates .used to 620 construct the Age Model (Fig. 2, Table 1) are shown the right of the Age scale

Figure 5. Principal Components 1 and 2, pollen flux (log (grains/ $\left.\mathrm{cm}^{\wedge} 2 / \mathrm{yr}\right)$, and sediment composition of Core LEDC10-01 plotted to age are shown with pollen zonation (I -VII). PC axis 1 is dominated by variability in Cupressaceae pollen. In PC axis 2, positive values indicate

625 Asteraceae and Amaranthaceae dominance, while negative values indicate Quercus and Pinus pollen dominance (Colors and symbols of the clusters and pollen flux derive from Figure 3). The relative amount of sand, silt, and clay, and \% carbonate are shown at the bottom of the figure.

Fig 6. Comparison of coastal southern California vegetation from four diagnostic pollen groups 630 deposited in Lake Elsinore and in Santa Barbara Basin between 9 ka and $\sim 33$ ka. For east of comparison, the very high frequency fluctuations in Pinus are smoothed with a 3-point moving average. Amaranthaceae, Asteraceae are grouped together as Herbs.

Figure 7. South coastal California marine and terrestrial paleoclimate reconstructions from 10

635 ka-33 ka. Positive loadings of LE PCI indicate greater effective moisture (Seneviratne, et al., 2010). Positive loadings of SBB PC 3 indicate greater presence of warm, stratified waters. Positive loadings of SBBPC1 indicate the presence of sub-arctic waters in SBB (Hendy, 2010).

Table 1. Chronology for LEDC10-1. 


\section{REFERENCES}

Adams, D.K., 1997. The North American Monsoon. Bulletin of the American Meteorological Society 78, 2197-2213.

645 Adams, J., Faure, Faure-Donard, McGlade, Woodward, 1990. Increases in terrestrial carbon storage from the Last Glacial Maximum to the present.

Anderson, R.G., Goulden, M.L., 2011. Relationships between climate, vegetation, and energy exchange across a montane gradient Journal of Geophysical Results 116, 1-16.

Anderson, R.L., Byrne, R., Dawson, T., 2008. Stable isotope evidence for a foggy climate on Santa Cruz Island, California at 16,600 cal. yr. B.P. Palaeogeography, Palaeoclimatology, Palaeoecology 262, 176-181.

Anderson, R.S., Power, M. J. Smith, S.J., et al., 2002. Paleoecology of a Middle Wisconsin Deposit from Southern California. Quaternary Research 58, 310-317.

Anderson, R.S., Starrat, Brunner, Jass, Pinter, N. 2010. Fire and vegetation history on Santa Rosa Island, Channel Islands, and long-term environmental change in southern California. Journal of Quaternary Science 25, 782-797.

Anderson, R.S., Koehler, P.A., 2003. Modern pollen and vegetation relationships in the mountains of Southern California, USA. Grana 42, 129.

Atwater, B.F., Adam, D.P., Bradbury, J.P., Forester, R.M., Mark, R.K., Lettis, W.R., Fisher, G.R., Gobalet, K.W., Robinson, S.W., 1986. A fan dam for Tulare Lake, California, and implications for the Wisconsin glacial history of the Sierra Nevada. Bulletin Geologic Society America 97, 97-109. 
Barbour, M.G., 2005. Vernal pool vegetation of California: communities of long-inundated deep habitats. Phytocoenologia 35, 177-200.

665 Barbour, M.G., Major, J., 1977. Terrestrial Vegetation of California. John Wiley \& Sons, New York.

Barlow, M., Nigam, S., Berbery, E.H., 2001. ENSO, Pacific Decadal Variability, and U.S. Summertime Precipitation, Drought, and Stream Flow. Journal of Climate 14, 2105-2128.

Barron, J., Heusser, L., Herbert, T., Lyle, M., 2003. High-resolution climatic evolution of coastal northern California during the past 16,000 years. Paleoceanography 18, doi:1029/2002PA000768,002003.

Barron, J.A., Anderson, L., 2010. Enhanced Late Holocene ENSO/PDO expression along the margins of the eastern North Pacific. Quaternary International 215, 34-44.

Blazevic, M.A., Kirby, M.E., Woods, A.D., et al., 2009. A sedimentary facies model for glacialage sediments in Baldwin Lake, Southern California. Sedimentary Geology 219, 151-168.

Bonny, A.P., 1978. The Effect of Pollen Recruitment Processes on Pollen Distribution Over the Sediment Surface of a Small Lake in Cumbria. Journal of Ecology 66, 385-416.

Branson, F.A., Miller, R.F., McQueen, I.S., 1967. Geographic Distribution and Factors Affecting the Distribution of Salt Desert Shrubs in the United States. Journal of Range Management 20, 287-296.

Brooks, T. M., Mittermeier, R. A., Mittermeier, C. G., et al., (2002). Habitat loss and extinction in the hotspots of biodiversity. Conservation biology, 16 (4), 909-923.

Brown, A.G., 2007. Monitoring fluvial pollen transport, its relationship to catchment vegetation and implications for palaeoenvironmental studies. Review of Palaeobotany and 685 Palynology 147, 60-76. 
Bryant Jr, V.M., Holloway, R.G., Jones, J.G., Carlson, D.L., 1994. Pollen preservation in alkaline soils of the American Southwest. Sedimentation of Organic Particles, 47-58

Byrne, R., Reidy, L., Kirby, M.E., et al., 2004. Changing Sedimentation Rates during the Last Three Centuries at Lake Elsinore, Riverside County, California. Regional Water Quality Board, Riverside, CA.

Campbell, I.D., 1999. Quaternary pollen taphonomy: examples of differential redeposition and differential preservation. Palaeogeography, Palaeoclimatology, Palaeoecology 149, 245256.

Castello, A.F., 2004. Winter precipitation on the US Pacific coast and El Niño-southern oscillation events. International Journal of Climatology 24, 481-497.

Cayan, D.R., 1984. Local Relationships between United States West Coast Precipitation and Monthly Mean Circulation Parameters. Monthly Weather Review 112, 1276-1282.

Cayan, D.R., Peterson, D.H., 1989. The influence of North Pacific atmospheric circulation on streamflow in the west. Geophysical Monograph Series 55, 375-397.

700 Clarke, O.F., Svehla, D., Ballmer, G., Montalvo, A., 2007. Flora of the Santa Ana River And Environs. Heyday Books, Berkeley, CA.

Cole, K.L., Liu, G.-W., 1994. Holocene paleoecology of an estuary on Santa Rosa Island, California. Quaternary Research 41, 326.

Coltrain, J.B., Harris, J.M., Cerling, C.E., et al., 2004. Rancho La Brea stable isotope biogeochemistry and its implications for the palaeoecology of late Pleistocene, coastal southern California. Palaeogeography, Palaeoclimatology, Palaeoecology 205, 199-219.

Cook, E., Woodhouse, C., Eakin, C.M., et al., 2004. Long-term aridity changes in the western United States. Science 306, 1015-1018. 
Corbosiero, K.L., 2009. The Contribution of Eastern North Pacific Tropical Cyclones to the Rainfall Climatology of the Southwest United States. Monthly Weather Review 137, 2415-2435.

Davis, O.K., 1999. Pollen analysis of a late-glacial and Holocene sediment core from Mono Lake, Mono County California. Quaternary Research 52, 243-249.

Dingemans, T., Mensing, S.A., Feakins, S.J., et al., 2014. 3000 years of environmental change at 715 Zaca Lake, California, USA. Frontiers in Ecology and Evolution 2.

Diffenbaugh, N.S., Ashfaq, M., 2007. Response of California Current forcing to mid-Holocene insolation and sea surface temperatures. Paleoceanography 22, n-a-n/a.

Fall, P.L., 1987. Pollen taphonomy in a canyon stream. Quaternary Research 28, 393-406.

Fletcher, K.E.K., Rockwell, T.K., Sharp, W.D., 2006. Late Quaternary slip rate of the southern 720 Elsinore fault, Southern California: Dating offset alluvial fans via $230 \mathrm{Th} / \mathrm{U}$ on pedogenic carbonate. Journal of Geophysical Research 116, 2156-2202.

Friddell, J.E., 2002. Direct comparison of marine and terrestrial climate variability during marine isotope stages 6 and 5: Results from Santa Barbara Basin ODP Hole 893A. Paleoceanography 17, 2-1-2-12.

725 Harrison, S.P., 2003. Mid-Holocene climates of the Americas: a dynamical response to changed seasonality. Climate Dynamics 20, 663.

Hendy, I.L., 2002. Apparent synchroneity of submillennial scale climate events between Greenland and Santa Barbara Basin, California from 30-10ka. Quaternary Science Reviews 21, 1167-1184. 
730 Hendy, I.L., 2010. The paleoclimatic response of the Southern Californian Margin to the rapid climate change of the last 60ka: A regional overview. Quaternary International 215, 6273.

Herbert, T.D., Schuffert, J., Andreasen, D., Heusser, L., et al., 2001. Collapse of the California Current during glacial maxima linked to climate change on land. Science 293, 71-76.

735 Heusser, L.E., 1995. Pollen stratigraphy and paleoecologic interpretation of the last $160 \mathrm{kyr}$ from Santa Barbara Basin, ODP Hole 893A., in: Kennett, J.P., Baldauf, J.G., Lyle, M. (Eds.), Proceedings of the Ocean Drilling Program, Scientific Results. Ocean Drilling Program, College Station, TX, pp. 265-279.

Heusser, L., Balsam, W.L., 1977. Pollen distribution in the northeast Pacific Ocean. Quaternary Research 7, 45-62.

Heusser, L.E., Hendy, I.L., Barron, J.A., 2014. Vegetation response to southern California drought during the Medieval Climate Anomaly and early Little Ice Age (AD 800-1600). Quaternary International, 1-13.

Heusser, L.E., Sirocko, F., 1997. Millennial pulsing of environmental change in southern California from the past 24 k.y.: A record of Indo-Pacific ENSO events? Geology (Boulder) 25, 243.

Heusser, L.E., Stock, C.E., 1984. Preparation techniques for concentrating pollen from marine sediments and other sediments with low pollen density. Palynology 8, 225-227.

Hidalgo, P.J., Galan, C., Dominguez, E., 1999. Pollen production of the genus Cupressus. Grana 38, 296-300.

Higgins, R.W., Yao, Y., Wang, X.L., 1997. Influence of the North American monsoon system on the U.S. summer precipitation regime. Journal of Climate 10, 2600-2622. 
Ibarra, D.E., Egger, A., Weaver, K., et al., 2014. Rise and fall of late Pleistocene pluvial lakes in response to reduced evaporation and precipitation: Evidence from Lake Surprise, California. Geological Society of America Bulletin. doi: 10.1130/B31014.1.

Inman, D.L., 1999. Climate Change and the Episodicity of Sediment Flux of Small California Rivers. The Journal of Geology 107, 251-270.

Jackson, S.T., 1999. Pollen dispersal models in Quaternary plant ecology: Assumptions, parameters, and prescriptions. The Botanical Review 65, 39-75.

760 Kennett, D.J., 2008. Wildfire and abrupt ecosystem disruption on California's Northern Channel Islands at the Ållerød-Younger Dryas boundary (13.0-12.9 ka). Quaterary Geochronology 27, 2530.

Kirby, M., Lund, S., Anderson, M., Bird, B., 2007. Insolation forcing of Holocene climate change in Southern California: a sediment study from Lake Elsinore. Journal of Paleolimnology 38, 395-417.

Kirby, M.E., 2005. Hydrologic variability and the onset of modern El Niño-Southern Oscillation: a 19 250-year record from Lake Elsinore, southern California. Journal of Quaternary Science 20, 239-254.

Kirby, M.E., 2006. Mid-Wisconsin sediment record from Baldwin Lake reveals hemispheric climate dynamics (Southern CA, USA). Palaeogeography, Palaeoclimatology, Palaeoecology 241, 267.

Kirby, M.E., Feakins, S.J., Bonuso, N., et al., 2013. Latest Pleistocene to Holocene hydroclimates from Lake Elsinore, California. Quaternary Science Reviews 76, 1-15. 
Kirby, M.E., Lund, S.P., Patterson, W.P., et al., 2010. A Holocene record of Pacific Decadal 775 Oscillation (PDO)-related hydrologic variability in Southern California (Lake Elsinore, CA). Journal of Paleolimnology 44, 819-839

Kirby, M.E., 2012. A 9170-year record of decadal-to multi cenetennials scale pluvial episodes from the coastal southwest United States: a role for atmospheric rivers? Quaternary Science Reviews 46, 57-65.

780 Kirby, M.E., Feakins, S.J., Bonuso, N., et al., 2013. Latest Pleistocene to Holocene hydroclimates from Lake Elsinore, California. Quaternary Science Reviews 76, 1-15.

Kirby, M.E., Feakins, S.J., Hiner, C.A. et al., 2014. Tropical Pacific forcing of Late-Holocene hydrologic variability in the coastal southwest United States. Quaternary Science Reviews 102, 27-38.

785 Koehler, P., Anderson, R.S., Spaulding, W.G., 2005. Development of vegetation in the Central Mojave Desert of California during the late Quaternary. Palaeogeography Palaeoclimatology Palaeoecology 215, 297-311.

Kueppers, L.M., 2005. Modeled regional climate change and California endemic oak ranges. Proceedings of the National Academy of Sciences - PNAS 102, 16281-16286.

790 Lawson, R., 2007. Stratification and mixing in Lake Elsinore, California: An assessment of axial flow pumps for improving water quality in a shallow eutrophic lake. Water Research (Oxford) 41, 4457-4467.

Lebreton, V., 2010. A neotaphonomic experiment in pollen oxidation and its implications for archaeopalynology. Review of Palaeobotany and Palynology 162, 29-38. 
795 Lichvar, R., Dixon, L., 2007. Wetland Plants of Specialized Habitats in the Arid West. Cold Regions Research and Engineering Laboratory US Army Corps of Engineers, Engineering Research and Development Center

Linton, M.J., Sperry, J.S., Williams, D.G., 1998. Limits to water transport in Juniperus osteosperma and Pinus edulis: implications for drought tolerance and regulation of transpiration. Functional Ecology 12, 906-911.

Loarie, S.R., 2008. Climate Change and the Future of California's Endemic Flora. PloS one 3.

Lynch, H.B., 1931. Rainfall and stream run-off in Southern California since 1769. . The Methropolitan Water District of Southern California, pp. 1- 31.

Lyle, M., Heusser, L., Ravelo, C., al., e., 2012. Out of the Tropics: The Pacific, Great Basin

805 Lakes, and Late Pleistocene Water Cycle in the Western United States. Science 337, 1629-1633.

Lyle, M., Heusser, L., Ravelo, C., et al., 2010. The Pleistocene water cycle and eastern boundary current processes along the California continental margin. Paleoceanography 25, , doi:10.1029/2009.

810 Lynch, H.B., 1931. Rainfall and stream run-off in Southern California since 1769. The Metropolitan Water District of Southern California, 31pp.

MacDonald, G.M., Kremenetski, K.V., Hidalgo, H.G., 2008. Southern California and the perfect drought: Simultaneous prolonged drought in southern California and the Sacramento and Colorado River systems. Quaternary International 188, 11-23.

815 Mann, J.F., 1951. The sediments of Lake Elsinore, Riverside County, California. Journal of Sedimentary Petrology 21, 151-161. 
Matthias, I., Giesecke, T., 2014. Insights into pollen source area, transport and deposition from modern pollen accumulation rates in lake sediments. Quaternary Science Reviews 87, 1223.

820 McDowell, N., 2008. Mechanisms of plant survival and mortality during drought: why do some plants survive while others succumb to drought? The New phytologist 178, 719-739.

McLaughlin, B.C., Zavaleta, E., 2012. Predicting species responses to climate change: demography and climate microrefugia in California valley oak (Quercus lobata). Global Change Biology 18, 2301-2312.

825 McLennan, D.S., 1984. Pollen transport and representation in the Coast Mountains of British Columbia. I. Flowering phenology and aerial deposition. Botany 62, 2154-2164.

Milliman, J.D., 2008. Climatic and anthropogenic factors affecting river discharge to the global ocean, 1951-2000. Global and Planetary Change 62, 187-194.

Myers, N., R. A. Mittermeier, C. G. Mittermeier, G. A. B. Da Fonseca, and J. Kent. 2000.

830 Biodiversity hotspots for conservation priorities. Nature 403: 853-858.

Milliman, J.D., 2008. Climatic and anthropogenic factors affecting river discharge to the global ocean, 1951-2000. Global and Planetary Change 62, 187-194.

Minnich, R.,2007. Southern California Conifer Forests, in: Barbour, M.G., Keeler-Wolf, T., Schoenher, A.A. (Eds.), Terrestrial Vegetation of California. University of California Press, Oakland, CA, p. 712.

Mueller, R.C., 2005. Differential tree mortality in response to severe drought: evidence for longterm vegetation shifts Drought-induced differential tree mortality. Journal of Ecology 93, 1085-1093.

Munz, P.A., 1974. A Flora of Southern California. University of California Press, Berkeley. 
840 Namias, J., Cayan, D.R., 1981. Large scale air-sea interactions and short-period climatic fluctuations. Science 214, 869-876.

Owen, L.A., 2003. Extreme southwestern margin of late Quaternary glaciation in North America: Timing and controls. Geology (Boulder) 31, 729.

Pisias, N., Mix, A., Heusser, L., 2001. Millennial scale climate variability of the northeast Pacific surface ocean and atmosphere based on radiolaria and pollen. Quaternary Science Reviews 20, 1561-1576..

Sangster, A.G., Dale, H.M., 1961. A preliminary stuudy of differential pollen grain preservation. Canadian Journal of Botany 39, 35-43.

Seager, R.,Y. Kushnir, C. Herweijer, N. Naik, and J. Velez, 2005. Modeling of tropical forcing of persistent droughts and pluvials over western North America: 1856-2000. J. Climate, $18,4068-4091$.

Solomon, A.M., Blassing, T.J., Solomon, J.A., 1982. Interpretation of floodplain pollen in alluvial sediments from an Arid Region. Quaternary Research 18, 52-71.

Sork, V.L., 2002. Pollen movement in declining populations of California Valley oak, Quercus lobata: where have all the fathers gone? Molecular Ecology 11, 1657-1668.

Thompson, R.S., Anderson, K.H., Bartlein, P., 1998. Atlas of relations between climatic parameters and distributions of important trees and shrubs in North America. U.S. Geological Survey, Washington D.C.

Trenberth, K.E., Hurrell, J.W., 1994. Decadal atmosphere-ocean variations in the Pacific. Climate Dynamics 9, 303-319.

Tschudy, R.H., Relationsip of palynomorphs to sedimentation, in: Tschudy, R.H., Scott, R.A. (Eds.), Aspects of Palynology. Wiley-Interscience, New York, pp. 79-96. 
Vasek, F.C., 1966. The distribution and taxonomy of three western junipers. Brittonia 18, 350372.

865 Vasek, F.C., Thorne, R.F., 1977. Transmontane coniferous vegetation, in: Barbour, M.G., Major, J. (Eds.), Terrestrial Vegetation of California. John Wiley \& Sons, New York, pp. 797834.

Vaughan, P., 1999. Paleoseismology of the Elsinore fault at Agua Tibia Mountain southern California. Bulletin of the Seismological Society of America 89, 1447-1457.

870 Vogl, R.J., 1973. Ecology of Knobcone Pine in the Santa Ana Mountains, California. Ecological Monographs 43,125-133.

Vogl, R.J., Schorr, P., 1972. Fire and Manzanita Chaparral in the San Jacinto Mountains, California. Ecology 53, 1179-1188.

Wahl, E., 2003a. Assiging climate values to modern pollen surface sample sites and validating modern analog climate reconstructions in the southern California region. Madroño 50, 271-285.

Wahl, E.R., 2003b. Pollen surface samples for paleoenvironmental reconstruction from the coast and Transverse Ranges of southern California. Madrono 50, 286-299.

Ward, J.K., Harris, J.M., al, e., 2005. Carbon starvation in glacial trees recovered from the La Brea tar pits, southern California. Proceedings of the National Academy of Sciences of the United States of America, 102, 690-694.

Warrick, J.A., 2008. Rapid formation of hyperpycnal sediment gravity currents offshore of a semi-arid California river. Continental shelf research 28, 991-1009. 
Wells, P.V., 1979. An equable glaciopluvial in the West: Pleniglacial evidence of increased precipitation on a gradient from the Great Basin to the Sonoran and Chihuahuan Deserts. Quaternary Research 12, 311-325.

Williams, A.P., 2012. Temperature as a potent driver of regional forest drought stress and tree mortality. Nature Climate Change 3, 292-297.

Willson, C.J., 2008. Hydraulic traits are influenced by phylogenetic history in the droughtresistant, invasive genus Juniperus (Cupressaceae). American journal of Botany 95, 299314.

Zhu, Y., Xie, Y., Cheng, B., Chen, F., Zhang, J., 2003. Pollen transport in the Shiyang River drainage, arid China. Chinese Science Bulletin 48, 1499-1506. 
Figure 1

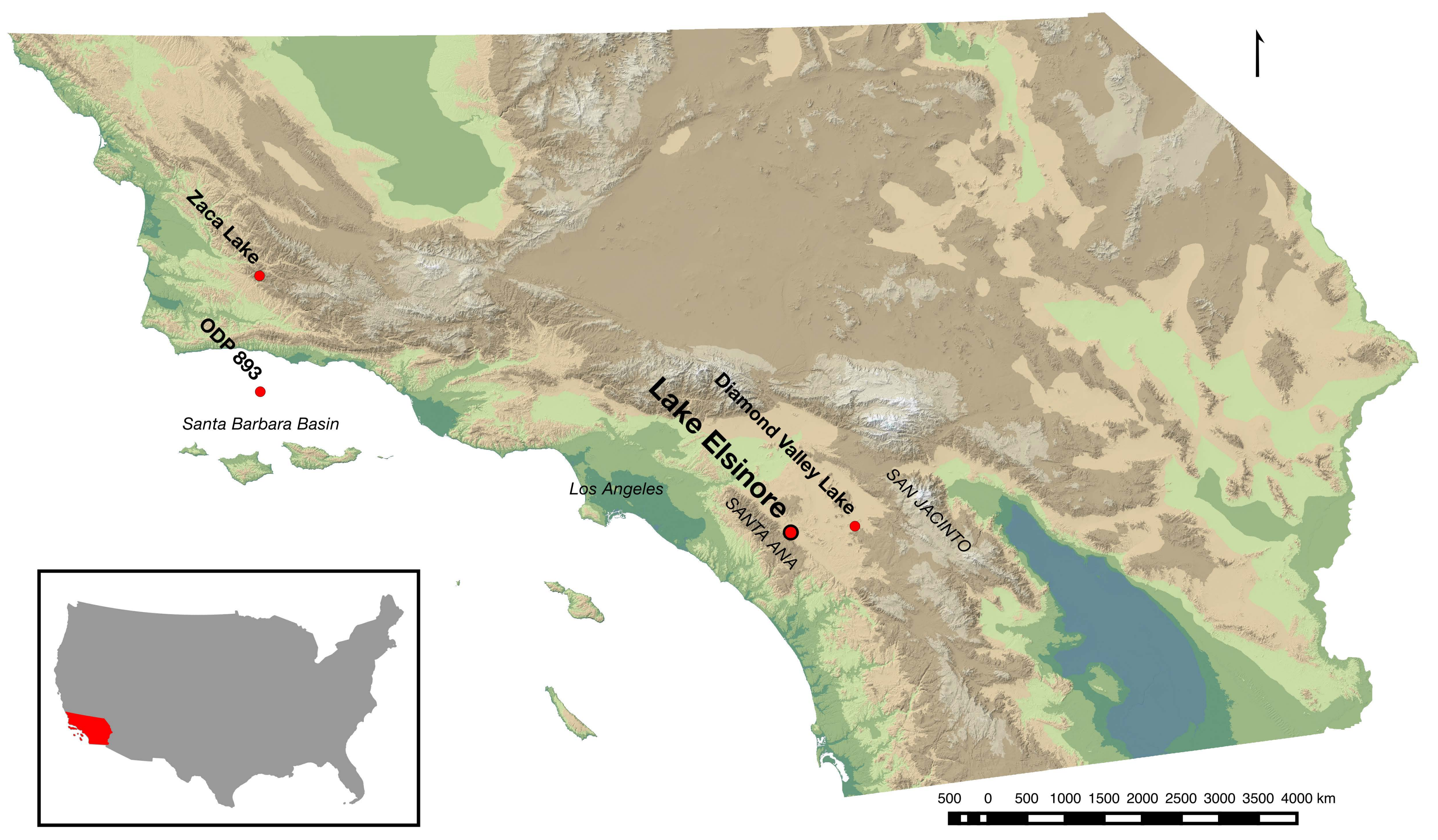


Figure 3 Principal Components Analysis
$-1.0$
$-0.5$
0.0
0.5
1.0

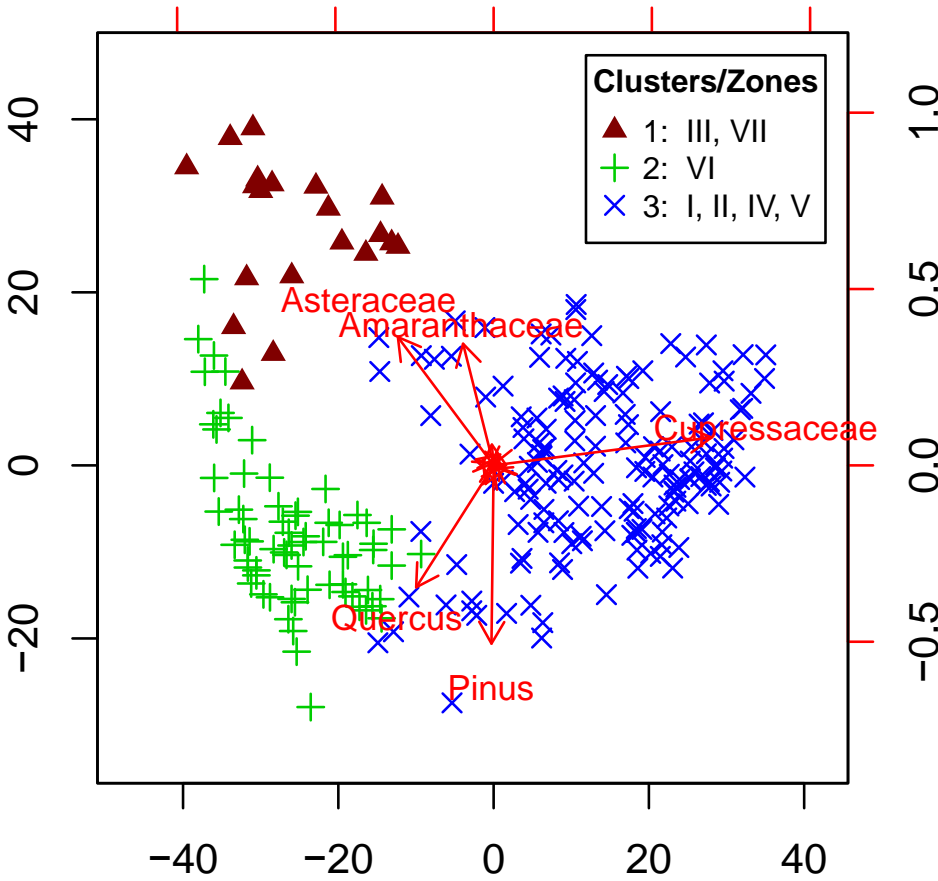

PC1, $56 \%$ of Variance Explained 
Figure 4

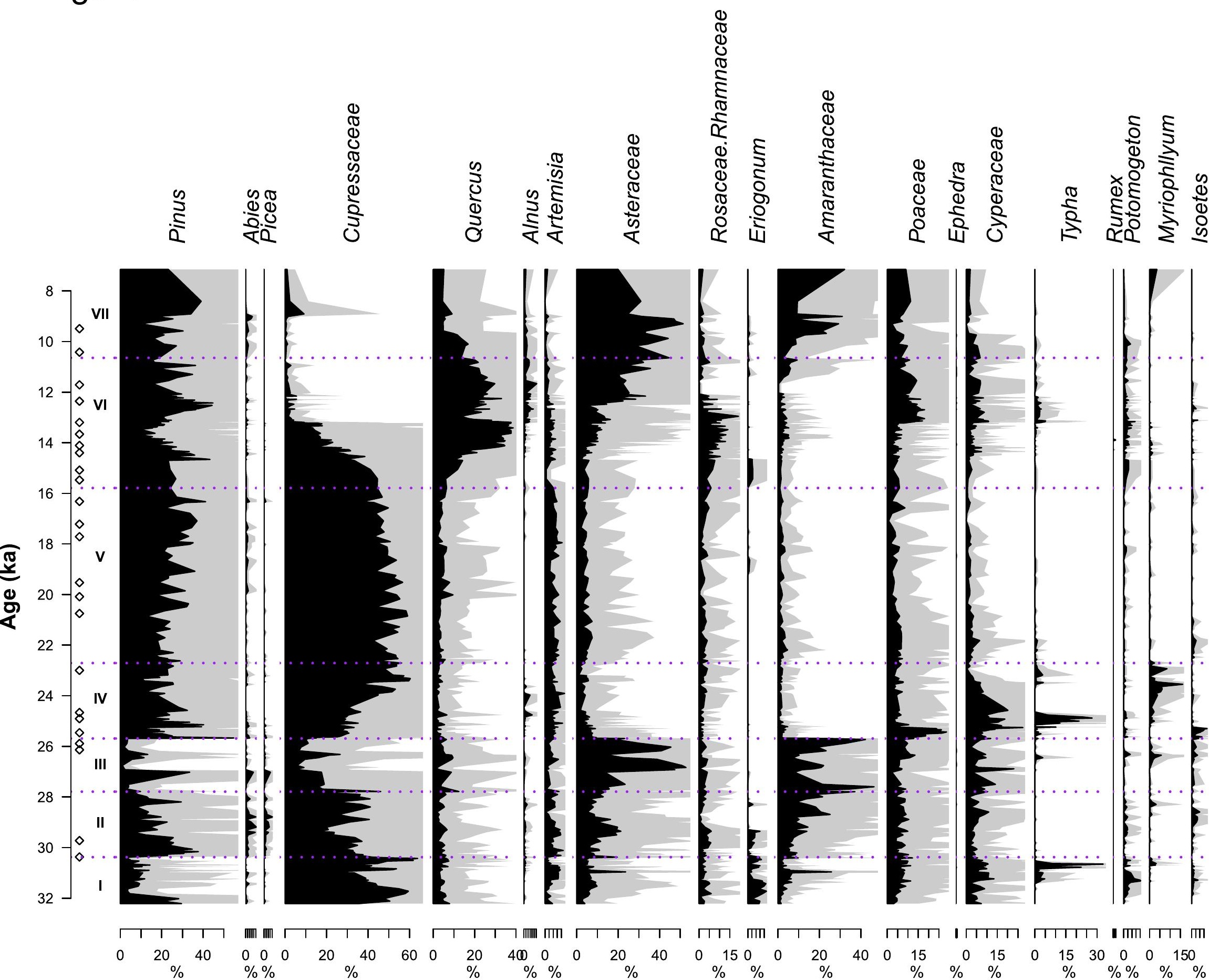


Figure $5 \quad$ VII $\quad$ VI

IV III II I

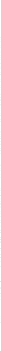

¿

$\frac{0}{x}$

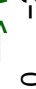

$\circ$

$10-4$

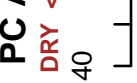

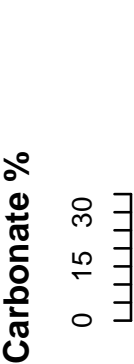
有禽

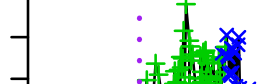

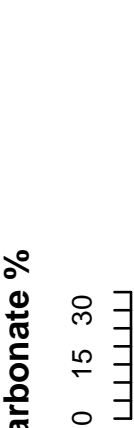

:

成

Clusters $\triangle 1$

$+2$ $\times 3$

:
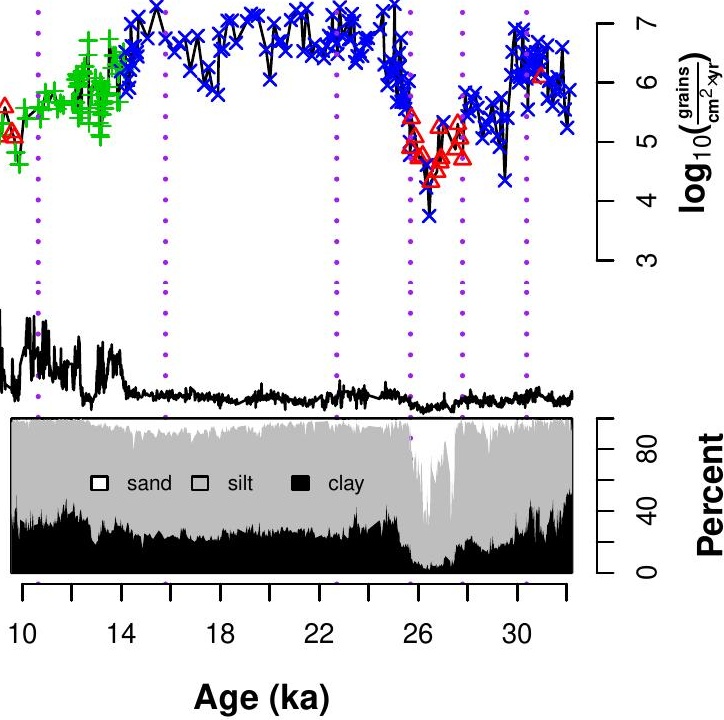
Figure 6

\section{Coastal Southwest CA Pollen}
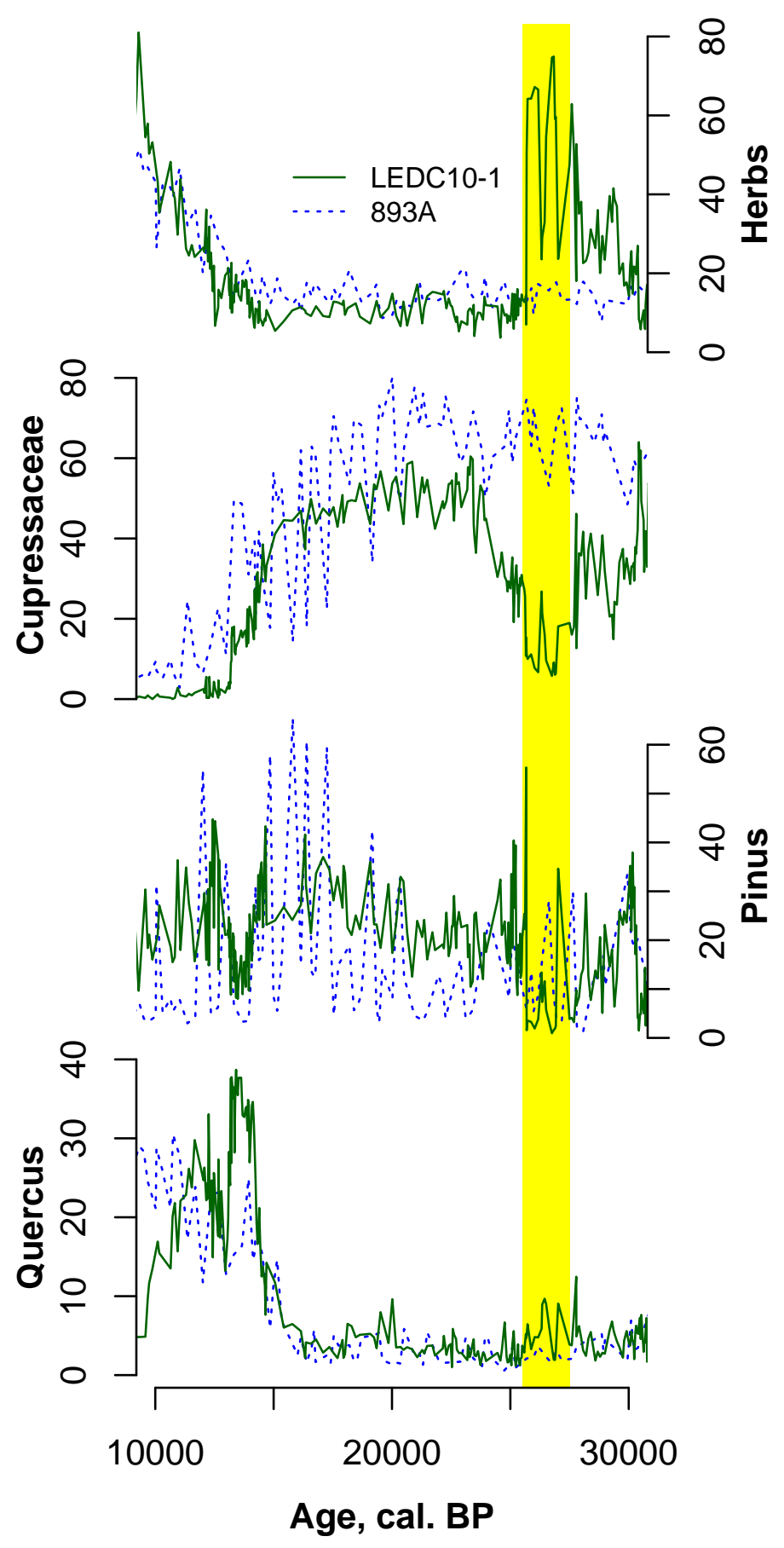
Figure 7

LEDC10-1 \& ODP893A
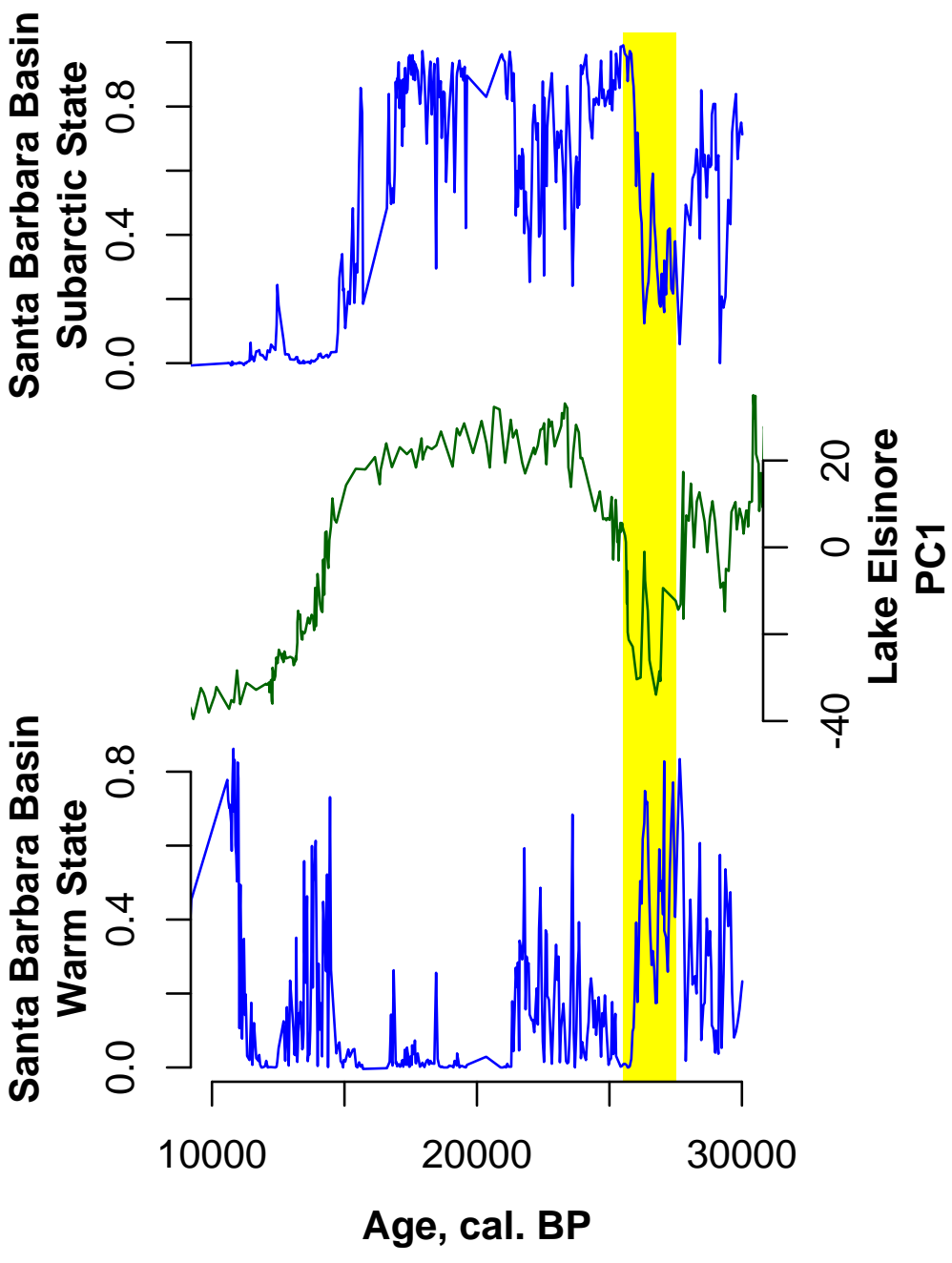